\title{
Occupational Exposure to Solid Aerosols during MIG Welding of Structural Carbon Steel
}

\author{
SZABOVA Zuzana ${ }^{1, a}$, CEKAN Pavol ${ }^{2, b}$, KURACINA Richard ${ }^{3, c}$ \\ and BALOG Karol ${ }^{4, d}$
}

\begin{abstract}
1, 2, 3 Slovak University of Technology in Bratislava, Faculty of Materials Science and Technology in Trnava, Department of Safety Engineering, Paulinska 16, 91724 Trnava, Slovak Republic

a zuzana.szabova@stuba.sk, b pavol.cekan@stuba.sk, ${ }^{\mathrm{c}}$ richard.kuracina@stuba.sk, d karol.balog@stuba.sk
\end{abstract}

Keywords: welding, safety, solid aerosols, workplace

\begin{abstract}
Safety and health of workers associated with the presence of solid aerosols in welding must be continuously monitored. The solid aerosols in the work environment and other factors are currently the serious problem of most workplaces not only in the European Union. Due to this fact is every profession potentially dangerous. This contribution will provide information on solid aerosols that are present at welding workplaces. It describes welding process and the conditions under which the measurement was carried out in relation with regulations. The article describes the specific measurement of solid welding aerosols in the work environment of welder. Samples of welding fume were collected from the breathing zone of a welder. The concentrations of solid aerosol were then compared with the limit values in accordance with legal regulations and were discussed measures to eliminate the risks.
\end{abstract}

\section{Introduction}

Welding is a common industrial process. A hazard that has both acute and long/term chronic effects is welding fume. Fumes are solid particles that originate from welding consumables, the base metal and any coatings present on the base metal. In welding, the intense heat of the arc or flame vaporizes the base metal and electrode coating. This vaporized metal condenses into tiny particles called fumes that can be inhaled. The thermal effects can cause agglomeration of the particles into particle chains and clusters that can be deposited in the human respiratory tract [1-4].

Particles harmful to health effects depend primarily on the particle diameter which is between 0.1 microns and 1.0 microns but especially of less than 0.4 microns (in this range is $98.9 \%$ of the particles). These ultrafine particles have the ability to penetrate into the pulmonary alveoli where they settle. They penetrate the alveoli from the blood stream through the blood vessel walls penetrate and settle in the body [6]. In Table 1 is shown the particle size range of particulate aerosols resulting from the most common types of welding and thermal cutting.

Table 1. Particle size resulting of various types of welding [7].

\begin{tabular}{|l|l|}
\hline Manual metal arc welding & The particle size is predominantly in the range of 0.01 to 0.4 microns. \\
\hline MAG welding & $\begin{array}{l}\text { Max. the proportion of particles in the size of } 0.01 \text { to } 0.05 \text { micron, a } \\
\text { small amount of more than } 0.2 \text { microns. When welding high-alloy } \\
\text { steel - vast particle size is about } 0.1 \text { microns. }\end{array}$ \\
\hline MIG welding & $\begin{array}{l}\text { Max. the proportion of particles in the size of } 0.01 \text { to } 0.05 \text { microns. } \\
\text { All particles are smaller than } 0.4 \text { microns. } \\
\text { The maximum proportion of the particles in the size of } 0.01 \text { to } 0.05 \\
\text { microns. }\end{array}$ \\
\hline Thermal cutting of metals & $\begin{array}{l}\text { The particle size was } 0.03 \text { microns. Agglomerated secondary } \\
\text { particles reach the size to } 10 \text { microns. }\end{array}$ \\
\hline
\end{tabular}




\section{Measurement of exposure to solid aerosols during MIG welding}

Measurement has been carried in a small company focuses on welding of steel construction, and company also finalized finished weldments. Measurement has been carried in the hall (dimensions: width $5 \mathrm{~m}$, length $16 \mathrm{~m}$, height $3.5 \mathrm{~m}$ ), where were placed five welding workplaces. Manufacturing hall had located a central exhaust system on the ceiling. It was measured exposure of welder to solid aerosols during MIG welding of structural carbon steel.

Individual departments are separated with welding curtains. Before measurements were measured values microclimate conditions in the workplace by TESTO $350 \mathrm{XL}$ :

- $\quad$ Temperature $=17,4^{\circ} \mathrm{C}$,

- Moisture $=49 \%$,

- Air flow rate $=0,02 \mathrm{~m} \cdot \mathrm{s}^{-1}$.

Employees work at fixed workplaces at various establishments according to their classification. Most employees work activities are carried out manually and repeated throughout the work shift. A single-shift operation with a duration of 8 hours, including the 30 - minute break. It has been evaluated the work of welders who worked with an electric welder - automatic welding machine MIG (wire diameter - $\phi 1 \mathrm{~mm}$, welding wire feed speed $-4,1 \mathrm{~m} / \mathrm{min}$, shielding gas flow rate $81 / \mathrm{min}$ ).

Daily job scheduling of the welder for 8-hour shift:

- Preparing to work (study of technical drawings, preparation of materials) - $180 \mathrm{~min}$.

- Welding of construction elements - $285 \mathrm{~min}$,

- Grinding of weldments - $60 \mathrm{~min}$,

- Break at work - 30 min.

Welder carries out activities in a forced kneeling position, sitting, standing. These positions affect the amount of solid aerosols in the worker's breathing zone.

Samples of solid aerosols were taken in the breathing zone of the employee by portable laser aerosol spectrometer - GRIMM 1108th The measuring chain comprises a software radial - symmetric probes, AC adapter, self-sampling pump with a guaranteed rate $1.21 / \mathrm{min}$ PTFE - membrane filters - $47 \mathrm{~mm}$ connecting cable that connects the device to the computer (Figure 1).

The device allows continuous analysis of dust from 0.3 to 20 microns, the measurement of the norm STN EN 481 and EN 689. The big advantage of the device is that the dust present value based on light scattering and gravimetric principle [10].

\section{Results and discussion}

Measurements were carried out without switching on suction (Figure 1) as well as under suction (Figure 2) .It can be seen that respirable (alveolic) concentration of particles that have harmful effect on health of employees is reduced when the suction is switched on. Reducing the concentration is very low due to inappropriate locations of the suction system in the ceiling of the hall.

The average fullshift concentration solid aerosols with possible fibrogenic effect and solid aerosols with mostly non-specific effects at work welder were calculated from the measured values according to EN 689 - Workplace atmospheres. Guidelines for the assessment of exposure by inhalation to chemical agents for comparison with limit values and measurement strategy [10]. 


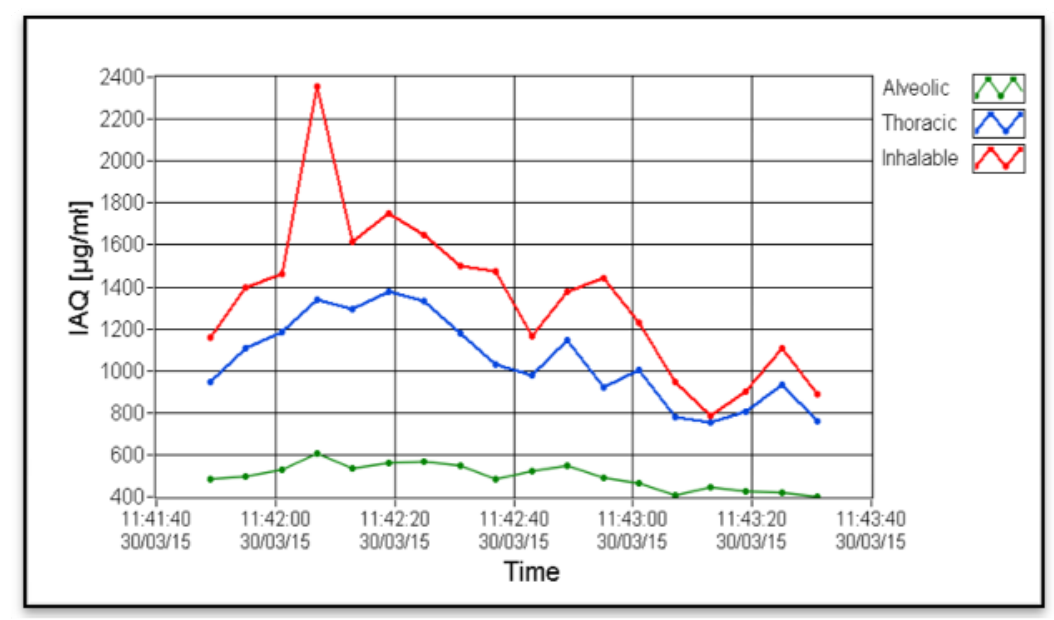

Figure 1. The concentration of solid welding aerosols without suction

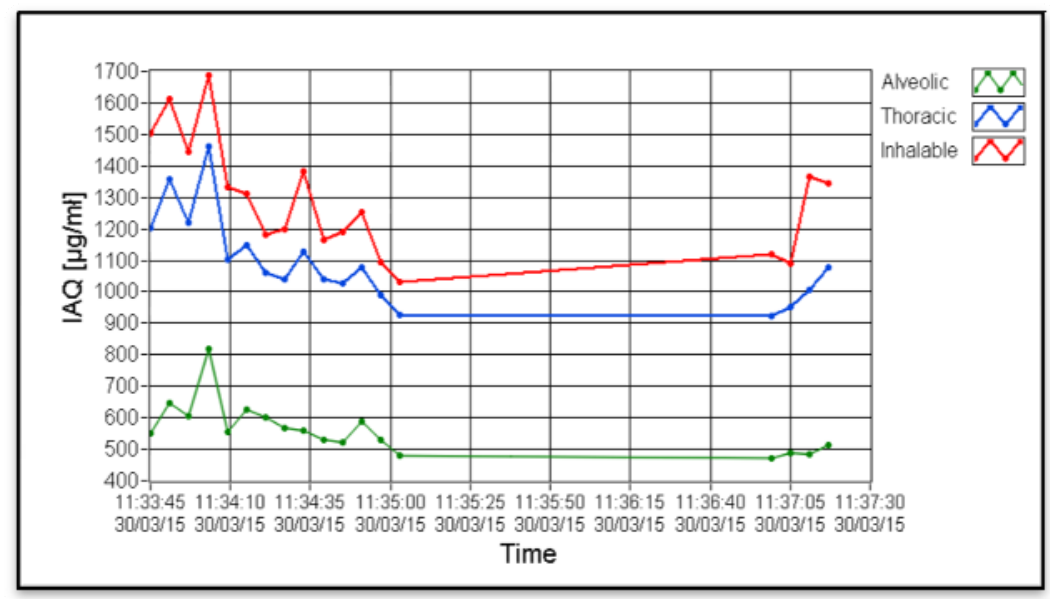

Figure 2. The concentration of solid welding aerosols with suction

Table 2 shows the calculated concentrations of solid aerosols for individual measurements realized during welding. Each concentration includes conversion to an 8-hour working time.

Table 2. Determination of concentration.

\begin{tabular}{|c|c|c|c|c|c|}
\hline $\begin{array}{l}\text { Sampling } \\
\text { point }\end{array}$ & $\begin{array}{c}\text { The average } \\
\text { concentration } \\
\text { within } 8 \mathrm{~h} \\
\text { changes to the } \\
\text { place of } \\
\text { collection } \\
\text { mg. } \mathrm{m}^{-3}\end{array}$ & $\begin{array}{c}\text { Average full shift } \\
\text { concentration } \\
\text { solid aerosols } \\
\text { mg.m } \text { m }^{-3}\end{array}$ & $\begin{array}{l}\text { Exposure limits / } \\
\text { NPEL / - for solid } \\
\text { aerosols } \\
\text { mg.m } \mathrm{m}^{-3}\end{array}$ & $\begin{array}{c}\text { Measur } \\
\text { ement } \\
\text { uncerta } \\
\text { inty } \\
0.49 \\
\text { mg.m }{ }^{-3}\end{array}$ & $\begin{array}{c}\text { Exposure } \\
\text { assessmen } \\
\mathrm{t} \\
\mathrm{mg} \cdot \mathrm{m}^{-3}\end{array}$ \\
\hline $\begin{array}{l}\text { M1 - } \\
\text { welding } \\
\text { suction }\end{array}$ & 10,1261 & 3,48 & \multirow{2}{*}{$\begin{array}{l}\text { with possible } \\
\text { fibrogenic effect - } \\
\text { welding solid } \\
\text { aerosols } \\
5.0\end{array}$} & 3,97 & \multirow{2}{*}{$\begin{array}{l}\text { Without } \\
\text { exceeding } \\
\text { NPEL }\end{array}$} \\
\hline $\begin{array}{l}\text { M2- } \\
\text { welding } \\
\text { without } \\
\text { suction }\end{array}$ & 8,9343 & 3,07 & & 3,56 & \\
\hline
\end{tabular}




\section{Conclusion}

The results of measurements of solid aerosols found exceeding of full shift average concentration of solid aerosols when compared with the maximum permissible limits of Slovak regulation (NV SR 355/2006). However, the only serious shortcoming that should be considered to ensure the workplace is removed with suction [8]. Exhaustion at the welding station should be forced general and local, used for extraction of welding fumes. [9]. It can be concluded that correct positioning of LEV should be implemented for effective exposure reduction.

Individual departments may have central air extractor, which is connected to a suction pipe, ensure extraction and management of smoke into the central extraction and filtration device that can be used for separation of pollutants from exhaust air. Clean filtered air can be in the summer led to the outside in winter into the hall space, which may lead to savings in heating respective halls $[1,9]$.

\section{Acknowledgements}

This paper was supported by the Cultural and Educational Grant Agency of the Slovak Republic, grant No. 028STU-4/2013 "E-learning as a Handbook of Health and Safety in Welding".

\section{References}

[1] H.S. Ashby, "Welding fumes in the workplace: Preventing potential health problems through proactive controls," Professional Safety, pp. 55/60, 2002.

[2] S.R. Fiore, "Reducing exposure to hexavalent chromium in welding fumes," Welding Journal, pp.38/43, 2006.

[3] Ravert ,"Controlling chromium fumes," Welding Journal, 2006.

[4] Hariri, A., Yusof, MD., Zainal, M., Abd Mutalib, L. (2013) Comparison of welding fumes exposure during standing and sitting welder's position. World Academy of Science, Engineering and Technology, 82 . pp. 640-643.

[5] Kosnac, L. Occupational health and safety in welding.1995.

[6] Pauliková, A., Beneová, A., Kapalo, P.: The ventilation system as part of worker protection at the welding workplace. 2014. [online]. [citované 5. mája 2014]. Dostupné na internete: $<$ http://www.tzbportal.sk/kurenie-voda-plyn/vetraci-system-ako-sucast-ochrany-praco vnika-na-zvaracom-pracovisku.html>.

[7] Kozmová, R.: Emissions from welded unalloyed and low alloyed steel MAG: In. ZVÁRANIE SVAŘOVÁNÍ, 2008, č. 10, s 281-283, ISSN 004-5525.

[8] NV SR 355/2006 Z. z. o ochrane zamestnancov pred rizikami súvisiacimi s expozíciou chemickým faktorom pri práci.

[9] Pauliková, A., Beneová, A. Welding workplace and its safety and environmental characteristics. 2014. [online]. [citované 5. mája 2014]. Dostupné na

internete: $<$ http://www.techpark.sk/technika-562011/zvaracie-pracovisko-a-jeho-bezpecnostne-a -environmentalne-charakteristiky.html>.

[10]STN EN 689 - Workplace atmospheres. Guidelines for the assessment of inhalation exposure to chemical agents for comparison with limit values and measurement strategy. December 2000. 